\title{
Minimally Invasive Lung Non-Mucinous Adenocarcinoma
}

National Cancer Institute

\section{Source}

National Cancer Institute. Minimally Invasive Lung Non-Mucinous Adenocarcinoma. NCI Thesaurus. Code C7269.

A morphologic variant of minimally invasive lung adenocarcinoma characterized by the presence of Clara cells and/or type II cells. 